\title{
METHODOLOGIES ASSOCIATED WITH EVALUATING ENVIRONMENTAL POLICY INTEGRATION (EPI) STRATEGIES \\ - THE CASE OF EUROPEAN UNION (EU) ENERGY POLICY
}

UDC 620.92:502/504

\author{
Vlastimir Vučić ${ }^{1}$, Miljana Radović Vučić ${ }^{2}$ \\ ${ }^{1}$ United International Business Schools (UIBS), Zurich Business School, Zurich, \\ Switzerland \\ ${ }^{2}$ University of Niš, Faculty of Sciences and Mathematics, Department of Chemistry, Niš, \\ Serbia
}

\begin{abstract}
Environmental policy integration (EPI) relates to the incorporation of environmental concerns in sectoral policies outside the conventional environmental policy domain. The sectoral policies have objectives that conflict environmental objectives and therefore have the perspective to influence root causes of environmental pressure. The integration between environment and energy policies is a standpoint upon which the EU has influenced energy governance. There is still a lack of precision how the relationship between both policies has transformed and modified energy policy. Ideally, the performance of EPI strategies is evaluated in terms of physical indicators such as $\mathrm{CO} 2$ emissions, environmental quality, reduction of climate risks, etc. Because this is difficult, if not impossible, reported levels of EPI relate to policy processes and outputs only. Marketbased mechanisms are regarded as an EPI strategy where they are implemented in sectoral policies. Recent studies have shown that these strategies can be efficient in stimulating environmental protection and that this depends on the price set and on enforcement. This paper proposes a model built around five aspects of policy support for renewable electricity (RES-E) production: type of policy scheme, level of support, duration of support, length of the administrative process and social acceptance. The purpose of this paper is therefore to contribute to more effective EPI strategies by developing a framework on the governance of EPI.
\end{abstract}

Key words: Environmental policy integration, energy policy, renewable electricity, market-based mechanisms

Received January 14, 2019 / Accepted April 22, 2019

Corresponding author: Vlastimir Vučić

United International Business Schools (UIBS), Zurich Business School, Brandschenkestrasse 38, 8002 Zurich,

Switzerland

E-mail: vlasta1504@gmail.com 


\section{INTRODUCTION}

Environmental policy integration (EPI) relates to the incorporation of environmental concerns in sectoral policies outside the conventional environmental policy domain [1]. Dealing with environmental concerns across sectors such as energy, transport, industry, housing, agriculture etc., and associated actors, each with differing priorities and interests is regarded as required, given that research indicates that the institutional specialization of policies for specific sectors results in a lack of consideration of environmental impacts [15]. The sectoral policies have objectives that conflict environmental objectives e.g. the lowering of water levels to stimulate agriculture resultant in drought-associated ecological impacts, and therefore, have the capacity to influence root causes of environmental pressure [1].

There is a consensus that the environmental concerns of the energy chain are the most significant drivers to influence European Union (EU) energy policy $[8,3,25]$. The integration between environment and energy policies is a standpoint upon which the EU has influenced energy governance [6]. However, there is still a lack of precision on how the relationship between both policies has transformed and modified energy policy. The studies on EPI suggest that only modest levels of policy integration have been reached. In fact, little is known about how to promote EPI and what factors stimulate or prevent the incorporation of environmental concerns in sectoral policies [1].

The purpose of this paper is, therefore, to contribute to more effective EPI strategies by developing a framework on the governance of EPI.

\section{LITERATURE}

\subsection{Environmental policy integration (EPI)}

The environmental implications of human activities urge the necessity to remedy them. Whether such a notion results in modified decision-making in conventional economic policy sectors is of consideration. The increasing concern implies that integration of environmental considerations into economic and social policies or EPI is a necessary shift in policy formulation and implementation and an essential component of SD. By strategically including all sectors the stance can be made to guide the society as a whole in a more sustainable manner.

EPI is a decision-making principle without reflecting too much on its meaning, thus suggesting that the perceived requirement for its clarity is of importance. To optimistically view EPI means bridging the gap between conventional environmental protection policy and ecologically sustainable society. To view EPI conceptually includes, however, dealing with a range of analytical ambiguities and opposing concepts. A manner of illustrating more convincing attitude is to disintegrate the term EPI into components.

According to the Cambridge Dictionary (2018) [4], the term "policy" is defined in the following way: "a set of ideas or plan of what to do in particular situations that has been agreed to officially by a group of people, a business organization, a government, or a political party". The definition illustrates the existence of a deliberate system of principles to manage decisions and achieve rational results. In relation to object to integrate, the term "policy" is, however, illustrated by vague definitions and multiple uses. Persson [24] uses the definitions by Hogwood and Gunn [10] to show a variety of contemporary uses of the term: as a process, as a theory or model, as an outcome, as an output, as a program, as official authorization, as decisions of government, as specific proposals, as an expression of purpose or 
state of affairs, and as a mark for a field of activity. Persson [24] points that policies "do not have clear beginnings and ends, nor is a policy practice necessarily a reflection of formal policy outputs". He refers to differences between policy levels, i.e. strategic policy frameworks (e.g. national energy strategy), specific policy instruments (e.g. energy subsidies) and technical policy implementation (e.g. guidelines for issuing solar panel installation), with explicit implications for the appropriateness and effectiveness of EPI strategy.

According to the Cambridge Dictionary (2018) [4], the term "integrate" means the following: "to combine two or more things in order to become more effective". Persson [24] uses the definition of the term "integrate" by Merriam-Webster's Collegiate Dictionary: "to form, coordinate, or blend into a functioning or unified whole; to unite with something else; to incorporate into a larger unit". He concludes that the integration process can take place different degrees of order and purposiveness, either through coordination according to a predefined set of rules or through random blending. Secondly, these definitions leave open the issue of hierarchy and priority among the parts to be integrated. That is why integration can happen with no priority (in effect, equal priority) of different parts or with differentiated priority. And lastly, the definitions suggest that integration can imply both unifying several parts into a (new) whole and incorporating one part into a larger (existing) unit.

The term "environmental policy" includes government measures aimed at: "1) assessing the state of environmental pollution; 2) evaluating this pollution in relation to the threat it poses to either human welfare (anthropocentric) or ecosystems (ecocentric); and 3) controlling polluting activities by means of regulations, economic incentives and/or training, moral persuasion, information campaigns and collaborative contractual arrangements with selected target groups" [14, p. 9]. Environmental policy goals involve the reduction of emissions or local immissions, the freezing of current emission or immission levels or the deceleration of forecasted growth rates. Also, pollution control can be achieved either by limiting certain activities that give rise to emissions (control of immission levels) or by means of basic preventive measures (changes in the emission source structure).

Meijers and Stead [22] find that the term "policy integration" (PI) relates mainly to cooperation between the organizations rather than to cooperation between sectoral departments within one organization. They, however, argue that inter-organizational policy formulation and implementation and intra-organizational policy formulation and implementation are similar in a way that different sectoral departments within one organization might operate as different organizations with smaller or greater extent of interdependence. They define PI as a "management of cross-cutting issues in policy-making that transcend the boundaries of established policy fields, and which do not correspond to the institutional responsibilities of individual departments" [22]. According to them, "integrated policy-making refers to both horizontal sectoral integration (between different departments and/or professions in public authorities) and vertical inter-governmental integration in policy-making (between different tiers of government), or combinations of both" [22]. Candel and Biesbroek [5] define PI as "an agency driven process of asynchronous and multi-dimensional policy and institutional change within an existing or newly formed governance system that shapes the system's and its subsystems' ability to address a crosscutting policy problem in a more or less holistic manner".

EPI can be distinguished from an environmental policy in that it is related to environmental policy issues becoming part of sectors rather than being a separate policy field. It commonly refers to the incorporation of environmental concerns in sectoral policies 
outside the conventional environmental policy domains. The literature reveals many different ways to define EPI: as a general objective, as an overall strategy, as a normative principle, as a process, as an outcome and as a specific strategy. The integration of environmental policies or "environmental policy integration" is defined as "the incorporation of environmental objectives into all stages of policy making in non-governmental policy sectors, with a specific recognition of this goal as a guiding principle for the planning and execution of policy" [15]. This principle should further be "accompanied by an attempt to aggregate presumed environmental consequences into an overall evaluation of policy, and a commitment to minimize contradictions between environmental and sectoral policies by giving principled priority to the former over the latter" [15]. Lenschow [18] defined EPI as "a first-order operational principle to implement and institutionalize the idea of sustainable development". In addition, the Brundtland Commission's report defined the term "sustainable development" as a "development that meets the needs of the present without compromising the ability of future generations to meet their own needs" [28].

EPI strategies found in the literature range from institutional and organizational to regulatory and financial $[12,13,15,23]$. No commonly accepted classification of these strategies has yet been developed. Furthermore, different authors have elaborated on how to measure EPI $[16,17,15]$. Ideally, the performance of EPI strategies is evaluated in terms of physical indicators such as $\mathrm{CO} 2$ emissions, environmental quality, reduction of climate risks, etc. [1]. Because this is difficult, if not impossible, reported levels of EPI relate to policy processes and outputs only, e.g. the extent to which environmental or climate concerns are considered in decision-making, and in qualitative terms. Although they are usually not defined as such, market-based mechanisms are regarded as an EPI strategy where they are implemented in sectoral policies. Recent studies have shown that these strategies can be efficient in stimulating environmental protection $[2,19]$ and that this depends on the price set and on enforcement [27].

A variety of explanations for the level of EPI achieved have been reported. These have pointed to the governance of EPI as the most important obstacle in the progress achieved. For instance, one important governance challenge is that environmental and sectoral objectives often conflict meaning that in trade-offs, sectoral objectives are often favored, and there is a lack of political will to give priority to environmental concerns $[16,9]$.

\subsection{Renewable energy (RE)}

According to the Cambridge Dictionary (2018) [4], the term "renewable energy" is defined in the following way: "energy that is produced using the sun, wind, etc. from crops, rather than using fuels such as oil or coal". Similarly, Lund [20] defined the term "renewable energy" as "energy that is produced by natural resources - such as sunlight, wind, rain, waves, tides, and geothermal heat - that are naturally replenished within a time span of a few years". RE includes the technologies that convert natural resources into useful energy services: "(1) wind, wave, tidal, and hydropower (including micro- and river-off hydropower); (2) solar power (including photovoltaic), solar, thermal, and geothermal; (3) biomass and bio-fuel technologies (including biogas); and (4) renewable fraction of waste (households and industrial waste)" [20].

Feed-in tariffs (FIT) and green certificate systems or quota obligations are the two most widely used policy instruments for renewable electricity (RES-E) production. To stimulate RES-E, FIT set the price to be paid for RES-E. Green certificate systems, on the 
other hand, set the quantity of RES-E to be generated or consumed [11]. FIT necessitate electricity producers, suppliers or consumers to buy RES-E that operators of RES plants feed into the grid, and to pay a fixed price for this RES-E. The fixed price is determined in advance for a period of several years and is paid by electricity suppliers to domestic operators of RES plants. Green certificate systems require electricity producers, suppliers or consumers to obtain a minimum quantity of green certificates that are issued for the production, supply or consumption of a specified amount of RES-E. The minimum quantity may be defined either as an amount in absolute units or as a percentage of electricity production or consumption. Compliance is monitored and eventual non-compliance is sanctioned through, for instance, fines or denial of access to the electricity grid.

\subsection{Research questions}

The purpose of this paper is, therefore, to contribute to more effective EPI strategies by developing a framework on the governance of EPI based on systematic empirical research organized around the following questions:

1. What strategies for supporting EPI have been found?

2. What evidence is presented about the performance of EPI strategies and how is the level of EPI measured?

3. To what extent are environmental concerns integrated in non-environmental policy sectors?

\section{METHODOLOGY}

\subsection{Development of research hypothesis}

A hypothesis is a "proposition that can be tested for association or causality against empirical evidence" [7]. Present research obtained research hypothesis based on the literature review. The main research hypothesis might be summarized as follows:

H1: Ceteris paribus, the likelihood of the intention to invest in renewable energy technologies (RET) increases with an increase in the perceived importance of the type of policy scheme for the production of electricity from renewable energy sources (RES-E).

$\mathrm{H} 2$ : Ceteris paribus, the likelihood of the intention to invest in renewable energy technologies (RET) increases with an increase in the perceived importance of the level of support for the production of electricity from renewable energy sources (RES-E).

H3: Ceteris paribus, the likelihood of the intention to invest in renewable energy technologies (RET) increases with an increase in the perceived importance of the duration of support for the production of electricity from renewable energy sources (RES-E).

H4: Ceteris paribus, the likelihood of the intention to invest in renewable energy technologies (RET) increases with an increase in the perceived importance of the length of the administrative process for production of electricity from renewable energy sources (RES-E).

H5: Ceteris paribus, the likelihood of the intention to invest in renewable energy technologies (RET) increases with an increase in the perceived importance of social acceptance for production of electricity from renewable energy sources (RES-E). 


\title{
3.2. Research design
}

Research can be understood as a process of finding solutions to a problem after a thorough study and analysis of the various factors. Business research can be understood as a methodical and organized effort to examine a particular problem encountered in the work setting that requires a solution. Sekaran and Bouqie [26] define business research as "organized, systematic, data-based, critical objective, specific inquiry or investigation into a specific problem, undertaken with the purpose of finding answers or solutions to it".

The present research is an exploratory research because there are no earlier studies to refer to for information about the issue. It will, therefore, look for patterns, ideas or hypotheses. Present research is also a qualitative research carried out to deal with the research questions and design a study that involves collecting qualitative data and analyzing them using interpretative methods. A questionnaire is a "research method for collecting primary data in which a sample of respondents are asked a list of carefully structured questions chosen after considerable testing, with a view to eliciting reliable responses" [7]. A sample comes from four sectors: venture capital, private equity, public capital markets and investment banking. The data collection method is by e-post. Finally, the present research is applied research designed to use it findings to solve a specific, existing problem.

\section{RESEARCH FINDINGS}

\subsection{Testing of a research hypothesis}

H1a: Ceteris paribus, the likelihood of the intention to invest in renewable energy technologies (RET) increases with an increase in the perceived importance of the type of policy scheme for the production of electricity from renewable energy sources (RES-E) (Fig. 1).

$\mathrm{H} 1 \mathrm{~b}$ : There is NO association between the investment in renewable energy technologies (RET) and the type of policy scheme for the production of electricity from renewable energy sources (RES-E) (Fig. 1).

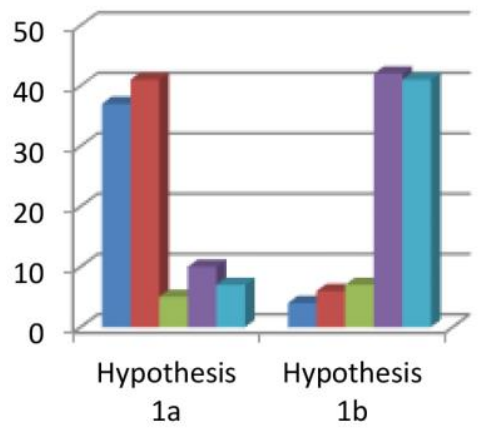

\author{
- Strongly Agree \\ agree \\ Neither Agree nor \\ Disagree \\ nisagree \\ n Strongly Disagree
}

Fig. 1 Hypothesis $1 \mathrm{a}$ and $1 \mathrm{~b}$ 
$\mathrm{H} 2 \mathrm{a}$ : Ceteris paribus, the likelihood of the intention to invest in renewable energy technologies (RET) increases with an increase in the perceived importance of the level of support for the production of electricity from renewable energy sources (RES-E) (Fig. 2).

$\mathrm{H} 2 \mathrm{~b}$ : There is NO association between the investment in renewable energy technologies (RET) and the level of support for the production of electricity from renewable energy sources (RES-E) (Fig. 2).

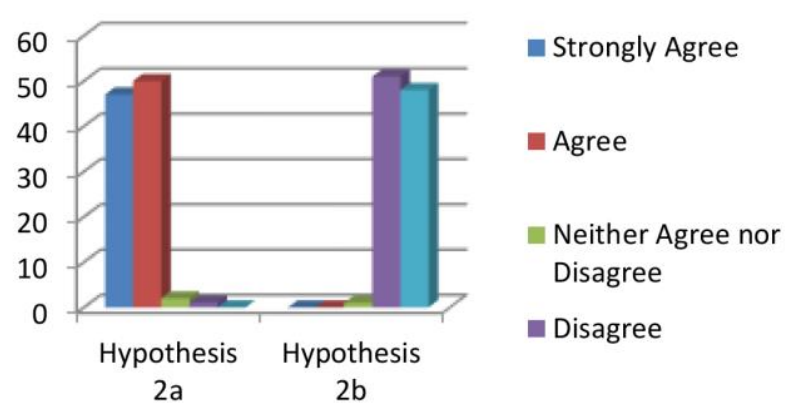

Fig. 2 Hypothesis $2 \mathrm{a}$ and $2 \mathrm{~b}$

H3a: Ceteris paribus, the likelihood of the intention to invest in renewable energy technologies (RET) increases with an increase in the perceived importance of the duration of support for the production of electricity from renewable energy sources (RES-E) (Fig. 3).

H3a: There is NO association between the investment in renewable energy technologies (RET) and the duration of support for the production of electricity from renewable energy sources (RES-E) (Fig. 3).

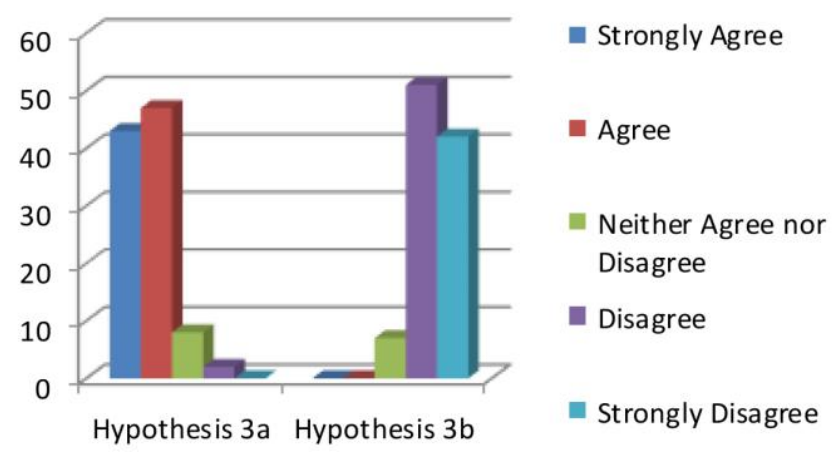

Fig. 3 Hypothesis $3 a$ and $3 b$

H4a: Ceteris paribus, the likelihood of the intention to invest in renewable energy technologies (RET) increases with an increase in the perceived importance of the length of the administrative process for the production of electricity from renewable energy sources (RES-E) (Fig. 4). 
H4b: There is NO association between the investment in renewable energy technologies (RET) and the length of the administrative process for the production of electricity from renewable energy sources (RES-E) (Fig. 4).

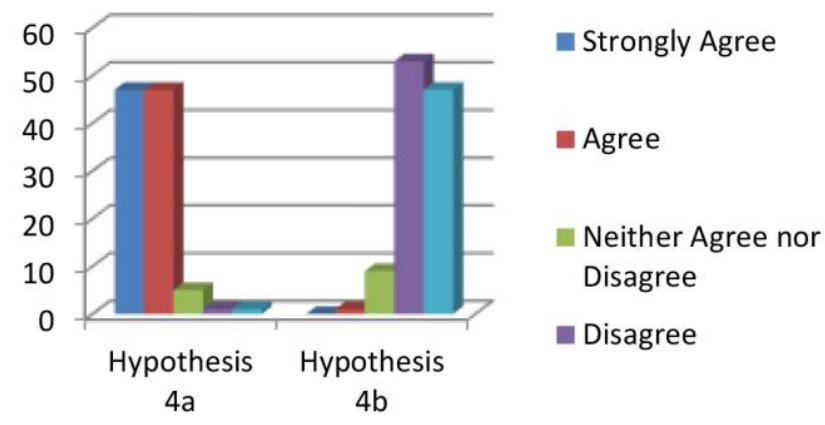

Fig. 4 Hypothesis $4 a$ and $4 b$

H5a: Ceteris paribus, the likelihood of the intention to invest in renewable energy technologies (RET) increases with an increase in the perceived importance of social acceptance for the production of electricity from renewable energy sources (RES-E) (Fig. 5).

$\mathrm{H} 5 \mathrm{~b}$ : There is NO association between the investment in renewable energy technologies (RET) and the social acceptance for the production of electricity from renewable energy sources (RES-E) (Fig. 5).

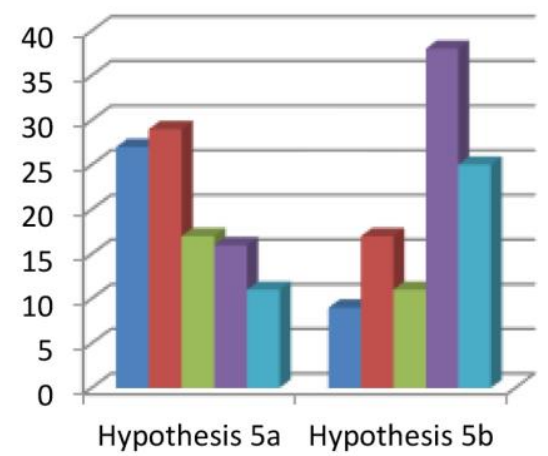

\author{
- Strongly Agree \\ Agree \\ Neither Agree nor \\ Disagree \\ Disagree \\ - Strongly Disagree
}

Fig. 5 Hypothesis $5 \mathrm{a}$ and $5 \mathrm{~b}$

\title{
5. SUMMARY, DISCUSSION, IMPLICATIONS AND CONCLUSIONS
}

When referring to the progress on integration it is useful to differentiate between EPI activities which are sector specific, such as the 2006 Green Paper on Energy and the Climate and Renewable Energy Package, and EPI activities which are cross-sectoral, such as the Sustainable Development Strategy (SDS) and the Cardiff Process. This stance allows differentiating integration directly related to the activities within the energy sector and integration taking place within the sector due to cross-sector EPI measures. 
Sector-specific initiatives appear more successful in promoting the integration of climate and energy issues at the EU level. For instance, climate change was one of the three policy objectives in the 2006 Energy Green Paper. Similarly, sectoral policy instruments have also been the most prominent mechanisms to contribute to the integration of climate and energy policies. One of the EU's flagship emissions reduction instrument in the sector is the FIT. The revisions of important instruments such as the RES Directives in the Climate and Renewable Energy Package included considerable improvements in design. It still remains to be seen if these changes will lead to significant improvements in implementation.

On the other hand, even though cross-sectoral EPI strategies are important for the integration of climate change into energy policy, they did not deliver considerable results. For instance, the SDS and the Cardiff Process resulted in significant opportunities for progress in a number of the EPI categories, namely political commitment, administrative culture and practice, and monitoring and learning. Even though these two high-level initiatives illustrated political support for EPI, they did not show a high level of political leadership for EPI. The SDS has not enjoyed the high level of interest shown towards the Lisbon Strategy for Growth and Jobs and the Cardiff Process has been a subject to a successive EU Presidencies. Due to the absence of this political leadership, these initiatives have not been adequately implemented at a sectoral level.

\section{REFERENCES}

1. Adelle, C., Russel, D. (2013). Climate Policy Integration: a case of déjà vu? Environmental Policy and Governance 23(1): 1-12.

2. Alvarado-Quesada, I., Hein, L., Weikard, H-P. 2014. Market-based mechanisms for biodiversity conservation: a review of existing schemes and an outline for a global mechanism. Biodiversity and Conservation 23: 1-21.

3. Buchan, D. (2009). Energy and Climate Change: Europe at the Crossroads, Oxford: Oxford University Press.

4. Cambridge Dictionary. (2018). https://dictionary.cambridge.org/

5. Candel, J.J.L., Biesbroek, G.R. (2016). Toward a processual understanding of policy integration. Policy Sci. 49, 211-231.

6. Collier, Ute. (2002). EU energy policy in a changing climate', in A. Lenschow (ed.), Environmental Policy Integration: Greening Sectoral Policies in Europe, London: Earthscan Publications, pp. 175-92.

7. Collis, J., Hussey, R. (2009). Business Research: A Practical Guide for Undergraduate \& Postgraduate Students. 3rd ed., London: Palgrave Macmillan.

8. Damro, C., Hardie, I. and D. MacKenzie. (2008). The EU and climate change policy: law, politics and prominence at different levels. Journal of Contemporary European Research, 4, 179-92.

9. Dupont C, Oberthür S. (2012). Insufficient climate policy integration in EU energy policy: the importance of the long-term perspective. Journal of Contemporary European Research 8(2): 228-247.

10. Hogwood, B. and L. Gunn (1984). Policy analysis for the real world. Oxford: Oxford University Press.

11. IEA (International Energy Agency) (2008), Deploying Renewables: Principles for Effective Policies, OECD/IEA, Paris.

12. Jacob, K., Volkery, A., Lenschow, A. (2008). Strategies for environmental policy integration in 30 OECD countries. In Innovation in Environmental Policy? Integrating the Environment for Sustainable Development, Jordan AJ, Lenschow A (eds). Edward Elgar Publishing: Cheltenham; $24-45$.

13. Jordan, A., Lenschow, A. (eds) (2008). Innovation in Environmental Policy? Integrating the Environment for Sustainability, Cheltenham, UK and Northampton, MA, USA: Edward Elgar Publishing.

14. Knoepfel, P. (Ed.) (2007). Environmental policy analyses. Learning from the Past for the Future -25 years of research. Berlin, Heidelberg, New York: Springer.

15. Lafferty WM, Hovden E. (2003). Environmental policy integration: towards an analytical framework. Environmental Politics 12(3): 1-22.

16. Lafferty WM, Knudsen J, Larsen OM. (2007). Pursuing sustainable development in Norway: the challenge of living up to Brundtland at home. European Environment 17(3): 177-188. 
17. Lafferty WM, Knudsen J. (2007). The Issue of 'Balance' and Trade-Offs in Environmental Policy Integration: How Will We Know EPI When We See it? EPIGOV Paper No. 11. Ecologic Institute for International and European Environmental Policy: Berlin

18. Lenschow, A. (2002). Environmental Policy Integration: Greening Sectoral Policies in Europe, Earth Scan, London.

19. Lu, Y., Zhu, X., Cui, Q. 2012. Effectiveness and equity implications of carbon policies in the United States construction industry. Building and Environment 49(1): 259-269.

20. Lund, H. (2010). Renewable energy systems: the choice and modeling of $100 \%$ renewable solutions. Academic, Burlington

21. Lund, H. (2014). Renewable Energy Systems: A Smart Energy Systems Approach to the Choice and Modeling of $100 \%$ Renewable Solutions, Academic Press

22. Meijers, E. and Stead, D. (2004). Policy integration: what does it mean and how can it be achieved? A multidisciplinary review. Paper presented at the 2004 Berlin Conference on Human Dimensions of Global Environmental Change, Freie Universität Berlin, 3-4 December.

23. Mickwitz, P., Aix, F., Beck, S., Carss, D., Nils, Ferrand N., Görg, C., Jensen, A., Kivimaa, P., Kuhlicke, C., Kuindersma, W., Máñez, M., Melanen, M., Monni, S., Pedersen, AB., Reinert, H., van Bommel, S. (2009). Climate Policy Integration, Coherence and Governance. PEER Report No. 2. Partnership for European Environmental Research: Helsinki.

24. Persson, A. (2004) Environmental Policy Integration: An Introduction. Policy Integration for Sustainability (PINTS). Background Paper. Stockholm Environment Institute. Stockholm.

25. Sandoval, I. (2011). Bridging the gap between environmental policy integration and the EU's energy policy: mapping out the "Green Europeanization" of energy governance. Journal of Contemporary European Research, 7 (3), 396-415.0

26. Sekaran, U., Bougie, R. (2009) Research Methods for Business: A Skill-Building Approach. 5th Edition, John Wiley and Sons Inc., Hoboken.

27. Ward, H., Cao, X. 2012. Domestic and international influences on green taxation. Comparative Political Studies 45(9): 1075-1103.

28. World Commission on Environment and Development (WCED) (1987), Our Common Future, Oxford: Oxford University Press.

\section{METODOLOGIJE POVEZANE SA PROCENOM STRATEGIJA INTEGRACIJE POLITIKE ZAŠTITE ŽIVOTNE SREDINE (EPI) - SLUČAJ ENERGETSKE POLITIKE EVROPSKE UNIJE (EU)}

Integracija politike zaštite životne sredine (EPI) odnosi se na uključivanje pitanja zaštite životne sredine u sektorske politike izvan područja konvencionalne politike zaštite životne sredine. Sektorske politike imaju ciljeve koji se sukobljavaju s ciljevima zaštite životne sredine i zato imaju potencijal da utiču na temeljne uzroke pritiska na zaštitu životne sredine. Integracija između politike zaštite životne sredine $i$ energetske politike je osnova na kojoj je EU uticala na upravljanje energetskom politikom. Još uvek nedostaje preciznost kako je odnos između tih politika promenio i izmenio energetsku politiku. $U$ idealnom slučaju, uspešnost strategija EPI-a procenjuje se u smislu fizičkih pokazatelja kao što su emisije CO2, kvalitet zaštite životne sredine, smanjenje klimatskih rizika itd. Budući da je to teško, ako ne i nemoguće, prijavljeni nivoi EPI-a odnose se samo na procese i rezultate politika. Tržišni mehanizmi smatraju se strategijom EPI-a ukoliko se provode u sektorskim politikama. Nedavne studije pokazale su da ove strategije mogu biti efikasne u podsticaju zaštite životne sredine $i$ da to zavisi od utvrđ̈enih cena $i$ sprovođenja. U ovom radu se predlaže model izgrađen oko pet aspekata politike podrške za proizvodnju električne energije iz obnovljivih izvora (OIE-E): vrsta podscticajne politike, nivo podrške, trajanje podrške, duzina administrativnog procesa i društveno prihvatanje. Svrha ovog rada je dakle doprineti efikansijim strategijama EPI-a kroz razvoj okvira za upravljanje EPI-jem.

Ključne reči: Integracija politike zaštite zivotne sredine, energetska politika, obnovljiva električna energija, tržišni mehanizmi 